\title{
A Critical Reflection on Developing and Implementing In-house EFL Textbooks
}

\author{
Una revisión crítica acerca del desarrollo y de \\ la implementación de libros de texto de inglés \\ contextualizados e institucionalizados
}

Astrid Núñez-Pardo*
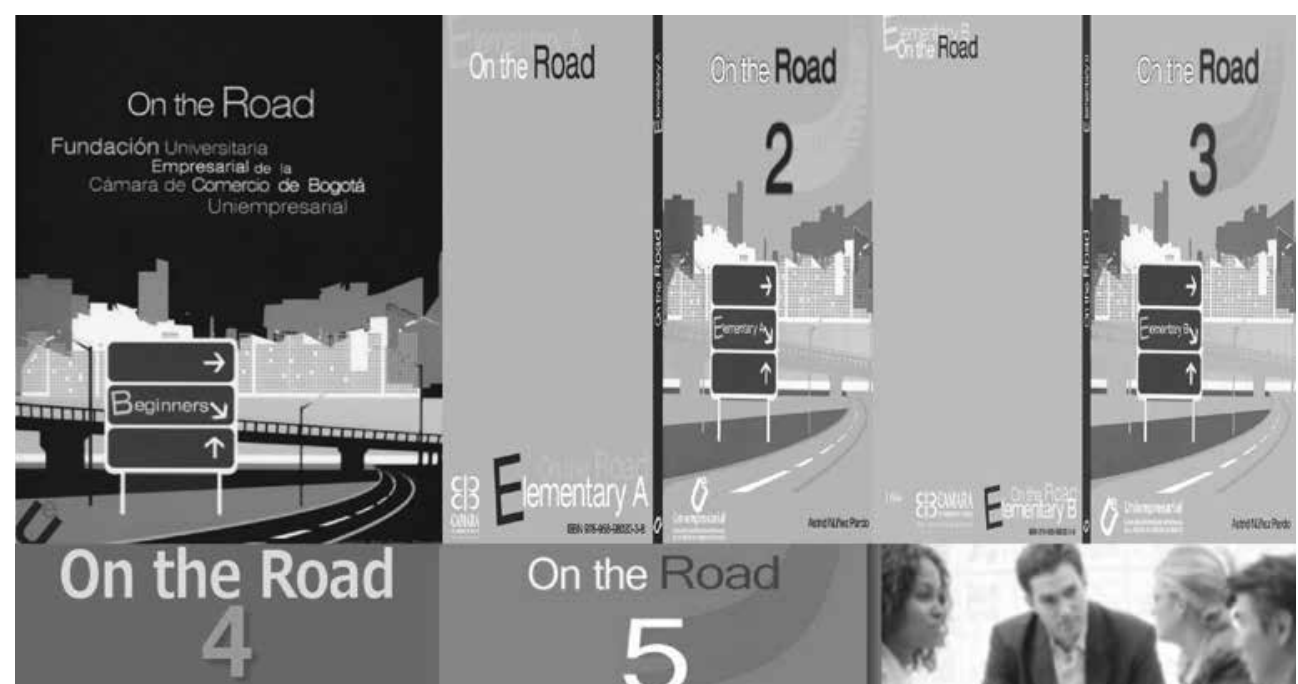

On the Road
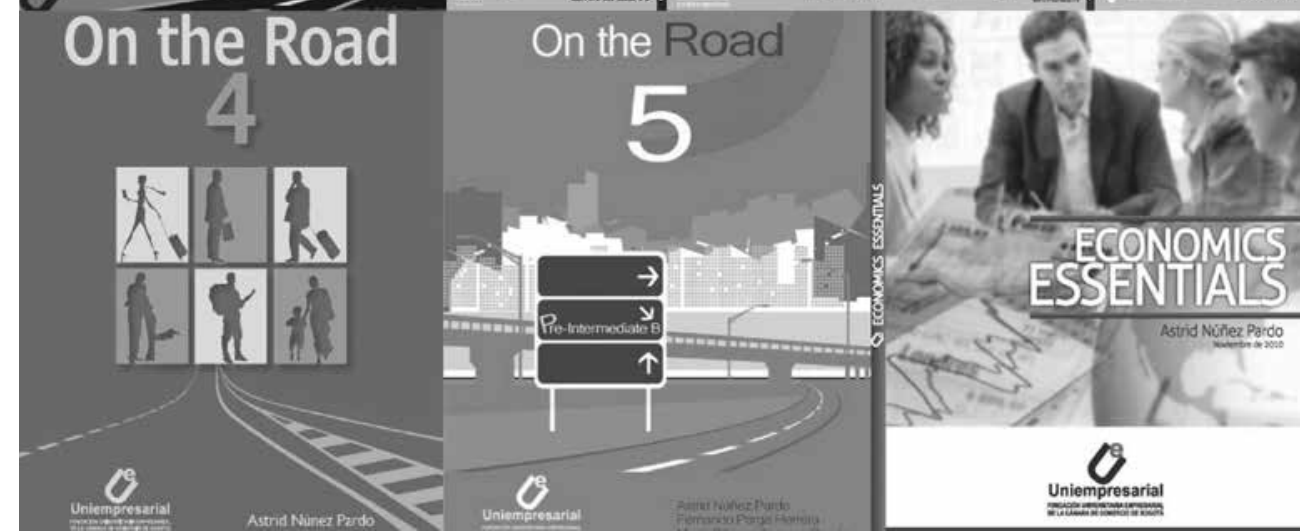

Citar este artículo como: Núñez-Pardo, A. (2020). A Critical Reflection on Developing and Implementing In-house EFL Textbooks. Revista Papeles, 11(21), 11-31.

Fecha de recibido: enero 15 de 2019 • Fecha de aceptación: abril 10 de 2019

* Astrid Núñez-Pardo, a full-time professor in the Master's Programme in Education at Universidad Externado de Colombia, is currently pursuing her PhD in Education at UPTC (Colombia). She holds an MA in Education, a Specialisation in International Economics, a BA in Hotel and Tourism Business Management from Universidad Externado de Colombia, and a Diploma in Linguistic Studies from the University of Essex (UK) and on Child Rights Classroom and School Management from Lund University, Sweden. Correo electrónico: astrid. nunez@uexternado.edu.co 


\begin{abstract}
This paper shares a reflection based on a qualitative research case study that looked into the pertinence of developing and implementing a six in-house strategy-based English textbook series that combines English for General Purposes (EGP) and English for Specific Purposes (ESP) among undergraduates in the dual model at a private university. The study was conducted with twelve undergraduates from four majors, three English teachers and the coordinator of the Foreign Language Centre of this university, who performed the role of the researcher and materials developer. The objectives underlying this work were to develop and implement in-house strategy-based textbooks and to characterise students and teachers' perceptions regarding their pertinence in the dual model. The information-compiling instruments used in the study were a focus-group interview (to collect students' perspectives on the relevance of merging EGP and ESP content in an English series), and field notes from the English teachers (to gather their perspectives as participants-observers of the process). After analysing the collected data, the findings of the study revealed that (a) there was an increasing awareness of English as the global language to foster academic development, professional performance and work opportunities; (b) the EGP and ESP blending was regarded as the ideal complement for dual model programmes; and (c) developing and implementing contextualised in-house materials were deemed to be a congratulatory effort in the quest of helping students learn. Developing and implementing in-house materials, in an English Programme for undergraduates in the dual model narrowed the gap between the purpose of the theory and the real needs of the business apprenticeship. Despite the achieved results regarding the pertinence of the contextualised in-house EFL textbooks, an unusual academic decision, that seemed subtly supported by several EFL teachers, banned the use of the series that had served as a learning awareness-raising pedagogical resource for undergraduates under the dual model of a private university.
\end{abstract}

Key words: materials development-in-house materials, EFL textbook, English for general purposes, English for specific purposes, learning strategies, theory-practice dual model.

\title{
Resumen
}

Este artículo es una reflexión sobre el caso de estudio cualitativo que exploró la pertinencia del desarrollo e implementación de una colección de seis libros de inglés contextualizados con propósitos generales y específicos, basados en contenido y estrategias de aprendizaje, en estudiantes de enseñanza superior bajo la teoría y la práctica del modelo dual de enseñanza. El estudio se realizó en una universidad privada, con doce estudiantes de cuatro programas académicos, tres profesores de inglés y la coordinadora del Centro de Lenguas Extranjeras, quien desempeñó el rol de investigadora y desarrolladora de materiales. Los instrumentos de recopilación de información utilizados incluyeron una entrevista de grupo focal y notas de campo de los maestros de inglés. Dos aspectos subyacen en esta investigación: el desarrollo e implementación de libros de texto de inglés contextualizados y la caracterización de las percepciones de los estudiantes con respecto a la relevancia de dichos materiales en el modelo dual. Los resultados sugieren que (a) hubo una sensibilización por parte de los estudiantes acerca del papel del inglés como lengua global para fomentar el desarrollo 
académico, el desempeño profesional y oportunidades de trabajo; (b) la combinación del Inglés para Propósitos Generales (EGP) y del Inglés para Propósitos específicos (ESP) se consideró como un complemento ideal para los programas del modelo dual; y (c) el proceso de desarrollo e implementación de materiales contextualizados se consideró un esfuerzo digno de congratulación para ayudar a los estudiantes a aprender. En resumen, desarrollar e implementar materiales contextualizados e institucionalizados en un programa de inglés para estudiantes de enseñanza superior en el modelo dual ayuda a reducir la brecha entre el propósito de la teoría y las necesidades reales que los estudiantes encuentran en sus prácticas empresariales. A pesar de los resultados sobre la pertinencia de los libros de texto contextualizados e institucionalizados, una decisión académica inusual aparentemente apoyada por algunos maestros de inglés con su actitud reticente suspendió el uso de la serie que había funcionado como un recurso pedagógico que generó consciencia en los estudiantes de educación superior bajo el modelo dual de una universidad privada.

Palabras clave: desarrollo de materiales, libro de texto de inglés institucional, inglés con propósitos generales, inglés con propósitos específicos, estrategias de aprendizaje, modelo dual.

\section{Introduction}

The teaching and learning of English have been fostered by the Colombian bilingual educational policy. For instance, the General Law of Education (Ley 115, 1994) sets the capacity of communicating in a foreign language as an objective for primary and secondary education. Along similar lines, the National Bilingual Colombia Programme (2004) expects to educate citizens who are capable of communicating in English, and to incorporate the country into the processes of universal communication, global economy and cultural aperture with internationally comparable standards (MEN 2006, [own translation]). This adoption of the reference levels stated in the Common European Framework of Reference (CEFR, 2006) are in tandem with the establishment of the Estándares Básicos de Competencias en Lenguas Extranjeras: inglés (2006), the Ley de Bilingüismo 1651 (2006), and the Guidelines for Bilingual Education in Colombia (2006) involved in pre-school, primary, secondary and higher education institutions, language centres, international cooperation agencies, and the EFL industry of didactic materials in bilingual education (English).
More recently, the English National Programme Colombia Very Well! (2015-2025) has been consolidated as a long-term multisectoral policy directed towards improving EFL education as well as personal, social, and economic progress. All in all, the bilingual educational policy aims at strengthening English competence at all educational levels of students and the labour force in Colombia.

Besides promoting bilingual (English) education and the development of the communicative competence in this language, this policy has also addressed language teaching and learning materials, especially EFL textbooks. However, policy management and operationalisation have maintained the "instrumental, regulatory, homogenizing and commercial nature of textbooks developed by foreign and local publishing houses" (Núñez-Pardo, 2018a, p. 230). It is then imperative to take actions that disrupt this tradition in the development and production of EFL materials, which also permeates the ways in which English is taught and learned. Local and foreign studies have confirmed that EFL textbooks play a central role in EFL education (Castañeda \& Rico, 2015; Davcheva \& Sercu, 2005). Moreover, the EFL "textbook 
not only survives, it thrives" (Hutchinson \& Torres, 1994, p. 316). In an international study, Castro and Sercu (2005) have reported that EFL Textbooks continue to be the most employed teaching resource in the teaching of languages, either published by a local or foreign publishing house, in countries like Mexico, Poland, Belgium, Bulgaria, Greece, and Spain, whereas in Sweden they use textbooks that are exclusively published by their own local publishing companies. Despite being widely used in EFL teaching, commercial EFL textbooks are decontextualized as they do not respond to the specific affective, academic, sociocultural, economic and aesthetic needs of the students (Canagarajah, 2005; Kumaravadivelu, 1994; Núñez-Pardo, 2018a, 2018b; Reimann, 2009; Rico, 2012). Thus, the teaching of a foreign language, and the supporting materials, need to undergo a change to respond to the particular needs of the contexts where English is taught and learned. In this sense, contextualised inhouse EFL materials constitute an innovative and pertinent alternative to the education of citizens - guaranteeing a more equitable, inclusive, and respectful future society, whose individuals recognise and value their own culture, and respect cultural diversity.

The vision and mission of the private university where this study was conducted are to offer educational services to form individuals that are able to produce, to compete and to generate aggregate value to organisations in an environment of increasing globalisation. Its purpose is to provide intelligent and innovative solutions to a variety of market demands addressing the needs of retail, wholesale, and enterprise sectors. Among those solutions, this university offers the language teaching services of its Foreign Language Centre (FLC) to help learners communicate, both orally and in written form, due to the fact that it is the most used language in business, communications and in the labour market worldwide. Despite offering a seven-level English programme for the undergraduates, the learning, reading, and writing outcomes were not satisfactory as explained in the following section.

Besides being considered pedagogical language teaching and learning means, cultural artefacts, devices, curricular elements, and knowledge mediators, materials like EFL textbooks "are socio-cultural resources that facilitate not only linguistic interaction but also cultural exchanges between the various human groups"

\section{A Perceived Problematic Situation}

In the educational context, textbooks of all major fields of knowledge "play a fundamental role in the teaching and learning processes" (Núñez-Pardo, 2018a, p. 234). As mentioned above, EFL textbooks "have been and continue being used as the main teaching and learning resources in EFL contexts" (Núñez-Pardo, 2018b, p. 1). Besides being considered pedagogical language teaching and learning means, cultural artefacts, devices, curricular elements, and knowledge mediators, materials like EFL textbooks "are socio-cultural resources that facilitate not only linguistic interaction but also cultural exchanges between the various human groups" (Núñez, Tellez \& Castellanos, 2013, p. 10); they are also pedagogical, didactic and cognitive mediations (Alzate, Arbeláez, Gómez \& Romero, 2005). In this view, EFL 
textbooks are expected to support socio-cultural encounters among learners from diverse cultural backgrounds.

The ultimate purpose of learning a language is to be able to communicate thoughts, feelings, personal stances and arguments of individuals living within a given setting. Since EFL textbooks "seek to make languages mean" (Gray, 2010, p. 2) in the particular context of the learners, they should comprise "a variety of adds-on to meet the demand for a local fit" (Kumaravadivelu, 2014, p. 75), and they should also be developed "by each community in relation to its history, needs, and aspirations" (Canagarajah, 2005, p. 199). Therefore, developing and implementing contextualised materials might enhance teachers' and students' teaching and learning of English in their particular contexts, respectively; as well as raise students' conscious understanding of the world in which they live.

Several years of conducting research on the development of contextualised materials for the learning and teaching of English, (Núñez, 2010a; Núñez-Pardo, 2018a, 2018b; Núñez, Ramos, \& Téllez, 2006; Núñez \& Téllez, 2009, 2012, 2015, 2018; Núñez, Téllez and Castellanos, 2012, 2017a, 2017b) and more recently on the analysis of the cultural component of these materials, (Núñez-Pardo \& Téllez-Téllez, 2020, in print) has allowed me to confirm and reconfirm the urgent need to localise the development of EFL textbooks. Although "there is very little interest in promoting local proposals that meet specific local realities" (Núñez, Téllez \& Castellanos, 2013, p. 11), teachers should resist "the use of decontextualised and standardised materials, ...[and] become producers, not consumers, of context-bound teaching resources" (Núñez \& Téllez, 2018, p. 83). By decentralising both the EFL textbook and the underlying methodologies, these resources are more likely to meet students' realities and thus, help them to make sense of learning a foreign language, to provide them the opportunity to reflect on their lived experiences within their own communities, and to propose alternative solutions to existing problems.

The Foreign Language Centre (FLC) at this private university had been offering a seven-level English programme with two components: English for General Purposes (EGP) with an emphasis on reading and writing and English for Specific Purposes (ESP) aimed at improving reading comprehension skills and achieving academic purposes. In doing so, the English programme opted for the use of two commercial series published by two renown foreign publishing conglomerates. Due to EFL teachers' reflection on the reduced and repetitive reading and writing activities proposed in the chosen commercial textbooks, and students' claim on the cost of these foreign books and the number of units dedicated to recycling, this private institution had to consider an alternative solution to this perceived problematic situation. On this basis, the FLC took the initiative of developing and implementing a contextualised in-house strategy-based English textbook series entitled 'On the Road' that combined EGP and ESP for undergraduates in the dual model at a private university. The series entailed four sections: EGP, ESP, test yourself, and self-assessment, and offered an audio CD to complement this printed material.

Contextualised "in-house materials" (Bedwell, 2012, p. 1; Núñez, 2010a, p. 37) are the resources of choice to resist uniformed, standardised, homogenised, and generic materials. Not surprisingly, there are several reasons to consider substituting commercial materials: first, their generic, bland and repetitive subject content; (Bedwell, 2012; Howard \& Major, 2005; Littlejhon, 2012); second, the mechanical work of grammar patterns (Kramsch, 1993; Núñez et al., 2013, Pulverness \& Tomlinson, 2013, Rico, 2012); third, the cultural bias and the marginalisation of diversity of local realities 
(Hotwatt \& Widdowson, 2004; Núñez-Pardo, 2018a, 2018b); fourth, the acritical implementation of foreign methodologies (Canagarajah, 2005; Giroux \& Simon, 1998; Kincheloe, 1993, Kumaravadivelu, 2014); and fifth, their prevailing economic interest (Álvarez, 2008; Canagarajah, 1999; Giroux, 2001: González, 2006; Núñez, 2018a; Rico, 2010; Usma, 2009; Tomlinson, 2003). Besides distorting the sociocultural function of EFL materials, these irregularities standardise or homogenise the pedagogical processes involved in the teaching of foreign languages.
It is a duty of English teachers to favour local initiatives (Harwood, 2010, Núñez \& Téllez, 2015; Rossner, 1998; Tomlinson, 2003) that foster the use of contextualized resources if they want to meet learners' genuine needs, instructional requirements and working demands in the present multicultural context. The previous concern motivated the FLC coordinator and the teachers to take the initiative in developing and implementing an in-house strategy-based English textbook series that combines English for General Purposes (EGP) and English for Specific Purposes (ESP) for undergraduates in the dual model at a private university.

\section{A Particular Setting}

This study was conducted in a private university that implements the dual theory-practice Dual Model (DM). It involves two learning settings: the classroom where students learn about diverse subject matters related to their fields of study and the real business world, where they are exposed to true everyday business situations by alternating three months of theory and three months of internship. This dual education model was expected to be a beneficial situation since numerous companies facilitate learning on the job and the students promote social development through networks of cooperation.

The English programme offered at the FLC was based on the combination of the Communicative Approach (CA) with the Cognitive Academic Language Learning Approach
(CALLA), in tandem with the development of contextualised and content-rich and strategy-based in-house materials. Since these contextualised materials are responsive to local needs, they were aimed to several purposes: (a) to enhance students' motivation to learn English; (b) to raise students' awareness of their own learning process through the conscious use of learning strategies; and (c) to encourage students to gain control of their own learning process. Additionally, the materials sought to strengthen students' four language skills in English and learning the contents of other disciplines. Finally, the content of the materials comprised their academic and professional contexts through learning activities that required the conscious and articulated application of a repertoire of learning strategies with different degrees of complexity.

\section{Theoretical Foundations}

The purpose of this study was to examine the relevance of developing and implementing contextualised in-house textbooks for undergraduates in the dual model at a private university. This university regards the development of in-house English teaching materials as an aid for students' academic progress and effective learning of English. Then, this study was based on four main constructs: materials development, the theory-practice alternance model, English for General Purposes (EGP) and English for Specific Purposes (ESP). 


\section{Critical Aspects of Materials Development}

\section{Conceptualising Materials Development (MD)}

This conception has started to change due to teachers' awareness of a massive EFL materials production that favours economic interest, the acritical use of foreign methodologies, and the imperative need to consider students' sociocultural, economic and academic needs in their particular contexts. Contemporary scholars such as Castro \& Sercu (2005), Davcheva \& Sercu (2005), Harwood (2010), Jolly and Bolitho (1998), Maly (1998), Núñez and Téllez (2009, 2015, 2018), Núñez et al., (2012, 2017a, 2017b); Núñez, Téllez, Castellanos and Ramos (2009); McDonough and Shaw (2003), Ramos y Aguirre (2014), Rico (2011), Tomlinson (1998, 2003), Tomlinson \& Masuhara, (2010), among many others, have realised that MD constitutes a field of study that goes beyond individuals' intuition and inspiration. Indeed, materials developers "draw on a wide array of theories and frameworks" (Harwood, 2010, p. 3), rely on "intuition and tacit knowledge" (Maly, 1998, pp. 220-221), and combine "reasoning and artistic processes" (Núñez \& Téllez, 2009, p. 175). Correspondingly, MD "is both a field of study and a practical undertaking" (Tomlinson, 2001, p. 66). Thus, the process of developing appropriate, relevant, challenging, and contextualised materials that respond to students' sociocultural, economic and academic background in their particular communities entails more than individuals' creativity.

As a field of study, MD deals with the theoretical foundations and procedures involved in the design, use, evaluation, selection, and research on language teaching materials. As a practical endeavour, it entails producing, adapting, and evaluating materials that either teachers or materials writers do for their classrooms and for sale or distribution (Tomlinson, 2013). Along similar lines, Núñez and Téllez (2015) have claimed that "language pedagogy and applied linguistics have recently recognised that MD is a field of study focused on the effect of materials on the teaching-learning process of a foreign language" (p. 57). Therefore, MD is an interactive academic practice that implies theoretical grounds and practical undertakings that should be nourished by the results of classroom teaching and research supported by the use of EFL materials.

However complete, this is not the only conceptualisation of MD. For instance, Graves (2000) has defined it as "the planning process by which a teacher creates units and lessons within those units to carry out the objectives of the course" (p, 149). Furthermore, Núñez et al. (2013) have further expressed that MD "as a field of study, demands an informed methodology that allows validating the efficiency, appropriateness and relevance of materials within the context of learning a language" (p. 10). For these reasons, Núñez, Pineda, and Téllez (2004) have affirmed that MD "should not turn into a meaningless task with the sole purpose of enjoying and keeping the students busy" (p. 130). Being aware of the contribution of this field to language learning and teaching, an additional aspect to be considered is the notion of EFL teaching and learning materials.

\section{Redefining materials}

Unexpectedly, in this university, developing in-house English teaching materials was considered an aid for students to achieve both academic progress and effective learning of English. Language teaching and learning materials have been defined as "cultural artefacts from which meanings emerge about ... particular ways of being, ... ways of using language, and particular sets of values" (Gray, 2013, p. 3), inasmuch as they are "forms of 
socio-cultural mediations that make it possible to get close to the different cultures" (Núñez et al., 2013, p. 7) and "powerful tools that function as sociocultural mediators" (Rico, 2010, p. 90). In this sense, materials, in particular EFL textbooks, guide and enhance teaching and learning, raise students' awareness of their learning process and of teachers' pedagogical practice, and serve as mediations in sociocultural interactions among learners from diverse cultural worlds.

\section{Typology of materials}

In a broad sense, EFL materials may be authentic and non-authentic. While the former refers to those that have been designed for universal or general communication, the latter denotes those developed with pedagogical or teaching purposes in mind (Carter, 1998; Gilmore, 2007; Harwood, 2010; Montijano, 2014; Thomas, 2014). Based on my personal and professional experience in developing, using and analysing EFL materials, I have perceived that authentic and non-authentic materials may be used as complementary sources in the quest of helping students learn a foreign language. Although authenticity seems to be a feature that stands out in teaching approaches and materials (Clarke, 1989), adaptation and simplification of dense contents facilitate learning (Swales, 1990). Moreover, attributes of the use of language in contexts can be present in simplified texts (Day \& Bamford, as cited in Harwood, 2010). This suggests that modification is needed in EFL materials that respond to students' requirements and interests of a particular class (Allwright, 1982; Harwood, 2010; Hutchinson \& Torres, 1994; O'Neill, 1990). However, the terms adaptation, simplification, and modification, maintain the idea - to a certain extent- of having teachers as consumers of marketable materials rather than as producers of their own ones.

\section{Reifying teachers as materials developers}

EFL teachers should ponder their roles as public intellectuals (Giroux, 2012), social and historical thinkers, and creators capable of transforming their contexts (Freire, 1998) - since they are "agents of permanent change" (Núñez \& Téllez, 2009, p. 184) and "critical change agents within their institutions' curriculum" (Núñez et al., 2017b, p. 60). The previous insights ratify the natural attribute of English teachers as developers of their own teaching materials. This is so, since "all teachers are potential materials developers" (Núñez \& Téllez, 2009, pp. 183-184) and because "there is a text developer in every teacher" (Graves, 1997, p. 67) and "every teacher is a materials developer" (Tomlinson, 2003, p. 1). Therefore, teachers' home-grown or home-made materials are responsive to the particularities of local classroom needs (Aebersold \& Lee, 2002; Núñez, 2010a; Núñez \& Téllez, 2015, Masuhara, 1998). Materials that consider institutional demands and students' context realities bring more possibilities for students to reach their academic and language learning goals. As Núñez and Téllez (2018) have stated, "Contextualised materials respond to ground realities of everyday-human life" (p. 37) - in accordance with the pedagogical reasons behind EFL materials.

\section{Substantiating contextualised materials}

Materials that are responsive to the needs of local teaching and learning contexts are contextualised ones. These materials are more pertinent than using foreign ones with alien cultural aspects of the bilingual educational Colombian context, and with frequent erratic settings of the English-speaking culture (de Mejía, 2006) that are not appropriate in other contexts (Pennycook, 1984). Considering contextual aspects closely related to learners' 
entire educational setting (McDonough, Shaw \& Masuhara, 2013) turn them into "contextbound [materials] since they are responsive to local needs ... and more meaningful and coherent to the sociocultural, economic, and political needs of local contexts" (Núñez et al., 2017a, pp. 34-26). Hence, contextualisation is central to in-house materials as this feature destabilises mainstream ways of developing standardized, homogenized, decontextualized and meaningless materials. Contextualised in-house materials offer more possibilities for students to make sense of learning a foreign language in context, develop a balanced set of language skills, and internalise content related to subject matters pertaining to their academic fields. These materials also give students the opportunity to exercise freedom in decision-making that let them reform or transform the experiences they lived within their own communities.
An additional aspect to be addressed in inhouse materials is the conscious use of learning strategies. These are mental procedures that aid both learners and teachers achieve their course goals. English teaching literature highlights the role of materials as a crucial element to enhance learning by means of the conscious use of strategies (Chamot, 2004; Chamot \& O’Malley, 1999; Núñez, 2010a; Oxford, 1997; Richards, 2001). As a result, the contextualised in-house materials proposed for the students enrolled in the dual model considered permanently exposing them to an array of learning strategies aimed at helping them become fully aware of their application in activity completion and in the self-construction of knowledge.

Having discussed the critical aspects of the first theoretical construct, the following section refers to the particularities of the dual model.

\section{The Theory-Practice Dual Model}

The theory-practice dual model contemplates two learning environments: The classroom and the real world. In the real world, the students are exposed to true everyday business situations by alternating three months of theory and three months of apprenticeship. This model promotes social development through networks of cooperation since students are expected to contribute to the productivity of the companies that participate in the program and the enterprises are supposed to facilitate learning by doing or learning on the job.

\section{The Combination of English for General and Specific Purposes (EGP and ESP)}

The EGP and ESP components of the English programme of this university respond to the institutional guidelines and to teachers' pedagogical knowledge and expertise in teaching EFL. Regarding EGP, and considering that the word "general" is vague, Strevens (as cited in Mohseni, 2008) has proposed the term "English for Educational Purposes (EEP) to account for a school-based learning of a language as a subject element within the school curriculum" (pp. 3-4). In relation to ESP, Belcher (2004, 2006) has declared that it is an umbrella term including EAP (English for Academic Purposes), EBP (English for Business Purposes), EOP (English for occupational purposes), or EMP (English for Medical Purposes), among others. It appeared back in the ' 60 s since EGP met neither leaner's nor employers' wants (Brunton, 2009). Nowadays, it makes an important part of communicative language 
teaching and EFL given that the English language has become a lingua franca in today's international business, politics, and economics world.

In relation to the causes that have given rise to ESP, Hutchinson and Waters (1987) have stated three reasons for its emergence: the demands of a brave new world, a revolution in linguistics, and a new focus on the learner. For Brunton (2009), ESP has increased over the decades as a result of market forces and a greater awareness amongst the academic and business community that learners' needs and wants should be met wherever possible" (p. 2). Correspondingly, no matter if it develops either the language-centred, the skills-centred or the learning-centred EGP or ESP approaches, the onset of course design ought to be the needs analysis.
Assessing both the learner's needs should be done to address them through the design of meaningful language-learning content-rich and strategy-based materials to attain the language-learning goals. In reference to this, researchers like Graves' (1997), Harwood (2010), Masuhara (1998), Núñez \&Téllez (2008, 2009, 2015), Pineda (2001), Seedhouse (1995) have stated that the content of the syllabus / curriculum and the resulting materials are generally seen as governed by needs. That is to say, that a meticulous analysis and assessment of the learners' personal (cultural and educational background) and learning needs (learning styles, previous experiences, language knowledge and proficiency) should be carried out as the departure point to syllabus design and in-house materials development.

\section{An Innovative and Challenging Pedagogical Design}

The pedagogical intervention of the current study entails the development and implementation of an in-house content-rich and strategy-based series of six textbooks of EGP and ESP to undergraduates in the theorypractice dual model. As the general objectives of the English programme at this private university was to attain students' learning of the English language as well as academic development, we developed contextualised materials that help students to select, comprehend, analyse, and respond to information in English. As a result, six contextualised inhouse EFL textbooks focused on the teaching of English with both general and specific purposes were published by the editorial of the university: On the Road for Beginners (Núñez, 2009), for Elementary $A$ (Núñez, 2010b), for Elementary $B$ (Núñez, 2011), for Pre-intermediate A (Núñez \& Quiroga, 2011), for Intermediate $B$ (Núñez, Parga \& Toquica, 2011); and a book on Economics Essentials (Núñez, 2010c) for the teaching of English with specific purposes.
Regarding the methodology that underpinned the series, the FLC opted for the merger of the Communicative Approach (CA) and the Cognitive Academic Language Learning (CALLA) approach. The former contemplates the linguistic knowledge, the socio-linguistic and the pragmatic aspects of the language (Canale \& Swain, 1980; and the Common European Framework of Reference, 2002). Under the CA, language is taught with communicative purposes and supported by both contents related to students' language learning and academic needs and learning strategies to maximise their intake. The latter advocates the teaching of subject contents and fosters the explicit instruction of learning strategies (Chamot \& O'Malley, 1999). The purpose of merging these approaches was to foster reading comprehension and the development of the writing skill through the contextualised in-house textbooks. It also aimed at improving discipline-specific vocabulary and raising motivation of students through topics pertaining to their academic programmes. 
The pedagogical design encompassed three main phases entailed: First, conducting a needs analysis through a survey and an analysis of progress tests. Second, inquiring students by means of a focus-group interview. Third, designing the syllabus and developing in-house materials by integrating procedures established in course design (Graves, 1997), the process for course and materials design (Núñez et al., 2004), the theoretical framework for MD (Núñez et al. 2012), and the scaffolding

\section{A Conventional Research Design}

This study was framed within the qualitative research approach. It focused on understanding a social reality lived in a real educational context using diverse data gathering instruments and being able to interpret participants' lived experiences and possible transformation (Burns, 1999; Hatch, 2002; Maxwell, 2008; Merriam, 2009; Sandin, 2003). This qualitative case study analysed a particular event in detail for MD (Núñez et al., 2009). In addition to this, some Second Language Acquisition (SLA) principles identified as relevant for developing materials (Tomlinson, 1988) were all taken into consideration to contextualise the series. Due to time constraints, the piloting phase of the pedagogical intervention (the six contextualised in-house EFL textbooks) could not be done. Missing the opportunity to pilot and adjust the books based on students' suggestions constitutes a major limitation of this research experience.

\section{Participants}

\section{Students}

Participants of the study were a sample of 12 undergraduates from four majors, four English teachers, and the coordinator-researcher of the Foreign Language Centre. The students at this university (the majority from Bogotá) were secondary-school graduates between the ages of 15 and 29 with a basic proficiency of English. They were enrolled in Business Administration (2 students), Environmental Management (1 student), Finances and Foreign Trade (7 students), and Marketing and Logistics (2 students). The four English teachers were aged between 29 and 63; their educational backgrounds include one B.A. in modern languages and language teaching, one M.A. in Education with emphasis on English Didactics, one M.A. candidate in Education with emphasis on English Didactics, and one M.A. candidate in Applied Linguistics. during a specific period of time, and in the natural context in which it occurs (Bell, 1993; Hitchcock \& Hughes, 1995; Zonabend, 1992; Yin, 1994). Hence, the research approach and the type of study suit this research experience as it analysed the perceptions of students and teachers regarding the relevance of developing and implementing in-house materials in university students under the dual model.

\section{The roles of the researcher}

The Coordinator of the FLC performed a dual role as a researcher and materials developer in all the stages of the study. First, the syllabus design was discussed with the English teachers based on students' learning needs. Second, the focus-group students were interviewed to learn about their perceptions on components, content, type of activities, learning, and the design of the English textbooks. Third, the six books of the seven-level series of English textbooks were developed and implemented. 


\section{Data Gathering Instruments}

The information-compiling instruments used in this study were a survey, which was useful to determine what the learners needed to achieve with the language (Pineda \& Núñez, 2001) and served as the onset for the development of in-house materials (Núñez \& Téllez, 2008). A focus-group (see Appendix A) served the purpose of collecting students' perspectives on the relevance of merging EGP and ESP content in an English series. Finally, teachers' field notes (see Appendix B) recount, register and report observations about in-class situations (Hopkins, 1995) that English teachers report as participants-observers of the process.

\section{Data analysis procedure}

Once the data were collected, the researcher followed the grounded theory approach to data analysis, originally envisioned by Strauss and Corbin (1994), later revisited in Corbin and Strauss (2008). The collected information was interpreted in Schwandt, Denzin and Lincoln's (1994) perspectives that embrace three types of triangulation: the methodological triangulation that implies using several sources for data collection; the theoretical triangulation that entails interpreting information gathered from more than one theoretical perspective; and the investigators' triangulation, which consists of having more than one researcher in the discipline collecting and interpreting data. Then, the grounded approach (Corbin \& Strauss, 2008) was considered to unveil the predominant concepts that lead to the establishment of three research subcategories and categories as mentioned in the following section.

\section{Findings}

Three categories answered the research concern: What is revealed about the development and implementation of an in-house strategybased English series that combines EGP and ESP for undergraduates in the theory-practice alternance or dual model? Firstly, students acknowledged the importance of English as the global language in their academic and professional achievement. Secondly, students deemed blending of EGP and ESP in-house materials as pertinent for students' motivation and academic and professional development. Thirdly, students qualified the contextualised in-house EFL textbooks as a praiseworthy endeavour. For a more detailed data analysis, readers may consult Núñez (2010a).

As confirmed by the above-mentioned categories, developing contextualised in-house materials restores teachers' and students' 'decision-making'; "the subjects ultimately involved in the teaching and learning of EFL" (Núñez-Pardo, 2018b, p. 2). More often than not, teachers and students hardly influence EFL textbooks design. Researchers like Apple (2004), Giroux (1997), Kumaravadivelu (2014), Littlejohn (2012) and Núñez-Pardo (2018b) have agreed that teachers and students should make decisions regarding the curriculum and materials. In other words, teachers and students should resist dependence on standardised materials that are obsolete and conservative and be a part of the creation of contextualised in-house textbooks as they are 'meaningful agents of change in ELT' (Hutchinson \& Torres, 1994). Such materials also constitute challenging socio-cultural mediations that respond to community realities and shape the ways in which students understand and build knowledge, developing a "critical and emancipatory conscience - both on the part of students and on the part of English teachers" (Núñez-Pardo, 2018a, p. 239). 


\section{Concluding remarks}

It is time for English teachers to critically undertake the scholarly activity of developing ELT materials by creating contextualised ones that respond to the local needs, interests, and life experiences of the learners in their own context. As Núñez (2010a) has attested, "Developing in-house materials makes it more feasible to address the demands of the institutional context and students' profiles, and to achieve academic and language learning goals" (p. 37). Rather than purchasing commercial courses, EFL teachers and students at this private university did fulfil their role as agents that influence the curriculum and materials in the dual model.

As mentioned earlier, three categories stand out in the present study. Students' recognition of English as the language for academic and professional achievement; their positive perception of blending EGP and ESP as a motivating aspect in academic and professional development; and the admirable endeavour of developing contextualised in-house EFL textbooks. Despite attaining positive results regarding the pertinence of the contextualised in-house EFL textbooks, an unusual academic decision subtly supported by the unwilling attitude of several EFL teachers banned the use of the series that had served as a learning awareness-raising pedagogical resource in undergraduates under the dual model of this private university.

\section{Limitations}

The results would not be complete without referring to their limitations. Students wondered about the book layout, especially illustrations and coloured illustrations, and the way of approaching grammar. The former responds to the low budget allocation this private university approved for the publication; it also conforms to the purchasing powers of the students enrolled in the academic programmes of this model. The latter refers to having students deduce grammar structures from written and oral texts, as well as from contextualised learning activities, which implied moving away from the conventional way of teaching grammar. The current study is also limited by the lack of piloting of the in-house EFL textbooks prior to their implementation -as mentioned earlier.

\section{References}

Aebersold, J., \& Lee, M. (2002). From reader to reading teacher. New York, NY: Cambridge University Press.

Álvarez-Valencia, J. A. (2008). Educational commercialism: $¿$ Is it overtaking EFL in Colombia? ASOCOPI Newsletter, p. 7.

Allwright, R. L. (1981). What do we want teaching materials for? ELT Journal, 36(1), 5-18.

Alzate, M., Arbeláez, M., Gallón, H., Gómez, M., \& Romero, F. (2005). El texto escolar y las mediaciones didácticas y cognitivas. Informe del proyecto Uso de los libros de texto de ciencias sociales e historia en grado $7^{\circ}$ de la educación básica secundaria en Colombia. Pereira: Colciencias-Universidad Tecnológica de Pereira.

Bedwell, C. (2012). A suggested writing process for in-house materials development. English Language Teaching World Online, 4, 1-9.

Belcher, D. (2004). Trends in teaching English for specific purposes. Annual Review of Applied Linguistics, 24, 165-186.

Belcher, D. (2006). English for specific purposes: Teaching to perceive needs and imagined futures in worlds of work, study and everyday life. TESOL Quarterly, 40(1), 133-156. 
Bell, J. (2005). Doing your research project. A guide for first-time researchers in education and social science. Berkshire, UK: Open University Press.

Brunton, M. (2009). An account of ESP-with possible future directions. English for Specific Purposes, 8(3), 1-15.

Burns, A (1999). Collaborative action research for English language teachers. New York, NY: Cambridge University Press.

Canagarajah, S. (2005). Introduction. In S. Canagarajah (Ed.). Reclaiming the local in language policy and practice (xiii-xxx). Mahwah, NJ: Lawrence Erlbaum Associates.

Canagarajah, S. (1999). Resisting linguistic imperialism in English teaching. Oxford, UK: Oxford University Press.

Carter, R. (1998) Orders of reality: CANCODE, communication and culture. ELT Journal 52(1), 3-56.

Castañeda, H., \& Rico, C. (2015). Rasgos característicos de la enseñanza en Colombia en el área de inglés como lengua extranjera. Análisis de las propuestas pedagógicas presentadas al premio Compartir al Maestro. Bogotá, Colombia: Fundación Compartir.

Castro, P., \& Sercu. L. (2005). Objectives of foreign language teaching and culture teaching time. In M. Byram \& A. Phipps. (Eds.). Languages for international communication and education (pp. 19-38). Trowbridge, Wiltshire, UK: Cromwell Press Ltd.

Chamot, A., \& O'Malley, J.M. (1999). CALLA handbook, implementing the cognitive academic language learning approach. Nueva York, NY: Addison-Wesley Publishing Company.

Chamot, A. U. (2004). Issues in language learning strategy research and teaching. Electronic Journal of Foreign Language Teaching 1(1), pp. 14-26

Clarke, D.F. (1989). Materials adaptation: why leave it all to the teachers? ELT journal 43 (2): 133-41.
Corbin, J., \& Strauss, A. (2008). Basics of qualitative research: Techniques and procedures for developing grounded theory. Thousand Oaks, CA: Sage Publications.

Davcheva, L., \& Sercu, L., (2005). Culture in foreign language teaching materials. In $\mathrm{L}$ Sercu (Comp). Foreign language teachers and intercultural competence. An international investigation (pp. 76-90). Clevedon, UK: Multilingual Matters Ltd.

de Mejía, A. M. (2006). Bilingual education in Colombia: Towards a recognition of languages, cultures and identities. Colombian Applied Linguistics Journal, (8), 152-168.

Freire, P. (1998). Pedagogía de la autonomía. México D.F., México: Siglo XXI Editores.

Gilmore, A. (2007). Authentic materials and authenticity in foreign language learning. Language Teaching 40 (2), 97-118.

Giroux, H., \& Simon, R. (1988). Schooling, popular culture, and a pedagogy of possibility. Journal of Education, 170(1), 9-26.

Giroux, H. (1997). Pedagogy and the politics of hope: Theory, culture and schooling. Oxford, UK: Westview Press.

Giroux, H. A. (2001). Public spaces, private lives: Beyond the culture of cynicism. New York, NY: Roman \& Littlefield.

Giroux, H. (2012). The disappearance of public intellectuals. In Counterpunch. Petrolia, California. Retrieved from http:// www.counterpunch.org/2012/10/08/ the-disappearance-of-public-intellectuals/

Graves, K. (1997). Teachers as course developers. New York, NY: Cambridge University Press.

Gray, J. (2010). The construction of English: Culture, consumerism and promotion in the ELT global coursebook. Basingstoke, UK: Palgrave Macmillan.

Gray J. (2013). Critical perspectives on language teaching materials. Hampshire, UK: Palgrave Macmillan Publishers Limited. 
González, A. (2006). On materials use training in EFL teacher education: Some reflections. PROFILE: Issues in Teachers' Professional Development, 7, 101-115. Bogotá: Universidad Nacional e Colombia.

Harwood, N. (2010). Issues in materials development and design. In B. Tomlinson (Ed.), English language teaching materials: Theory and practice. (pp.3-23). New York, NY: Cambridge University Press.

Hatch, J. A. (2002). Doing qualitative research in education settings. Albany, NY: State University of New York Press.

Howard, J., \& Major, J. (2005). Guidelines for designing effective English language teaching materials. The TESOLANZ Journal, $12,50-58$.

Howatt, A.P.R., \& Widdowson, H.G. (2004). $A$ history of English language teaching. Oxford, UK: Oxford University Press.

Hutchinson, T., \& Torres, E. (1994). The textbook as agent of change. ELT Journal, 48(4), 315-328.

Hutchinson, T., \& Waters, A. (1987). English for specific purposes: A learning-centered approach. New York, NY: Cambridge.

Hitchcock \& Hughes (1995). Research and the teacher: a qualitative introduction to school-based research. Glasgow, UK: Cambridge University Press.

Hopkins D. (1995). A teacher's guide to classroom research. Buckingham, UK: Open University.

Jolly, D., \& Bolitho, R. (1998). The process of materials writing. In Tomlinson, B. (Ed.), Materials development for language teaching. (pp. 90-115). Cambridge, UK: Cambridge University Press.

Kincheloe, J. L. (1993). Toward a critical politics of teacher thinking: Mapping the postmodern. Westport, CT: Bergin \& Garvey.
Kramsch, C. (1993). Context and culture in language teaching. Oxford, UK: Oxford University.

Kumaravadivelu, B. (1994). The post-method condition: (E)merging strategies for second/foreign language teaching. TESOL Quarterly, 28(1), 27-48.

Kumaravadivelu, B. (2014). The Decolonial Option in English Teaching. Can the subaltern act? TESOL Quarterly, 14(1), 66-85.

Littlejohn, A. (2012). Language teaching materials and the (Very) Big Picture. Electronic Journal of Foreign Language Teaching. 9(1), 283-297.

Mc Donough, J., \& Shaw, C. (2003). Materials and methods in ELT: A teacher's guide. Malden, MA: Blackwell Publishing.

McDonough, J., Shaw, C., \& Masuhara, H. (2013). Materials and methods in ELT: A teacher's guide (3rd Ed.). Oxford, UK: John Wiley \& Sons.

Maly, A. (1998). Squaring the circle-reconciling materials as constraints with material as empowerment. In B. Tomlinson, (Ed.), English language learning materials: $A$ critical review (pp.183-198). London, UK: Continuum.

Masuhara, H. (1998). What do teachers really want from coursebooks? In Tomlinson, B. (Ed.), Materials Development for Language Teaching. (pp. 239-260). Cambridge, UK: Cambridge University Press.

Maxwell, J. A. (2008). Designing a qualitative study. The SAGE handbook of applied social research methods, 2, 214-253.

Merriam, S. B. (2009). Qualitative research: a guide to design and implementation. San Francisco, CA: John Wiley \& Sons.

Ministerio de Educación Nacional [MEN]. (1994). Ley General de Educación (Ley 115 del 8 de febrero, de 1994) Retrieved from http://www.mineducacion.gov.co/ 1621/ articles-85906_archivo_pdf.pdf 
Ministerio de Educación, Cultura y Deporte (2002). Marco común de referencia para la enseñanza, aprendizaje y evaluación de las lenguas. Madrid, España: Artes Gráficas Fernández Ciudad S.L.

Ministerio de Educación Nacional [MEN] (2004). El programa nacional de bilingüismo. Retrieved from: www.mineducacion.gob.co

Ministerio de Educación Nacional [MEN] (2006). Estándares básicos de competencias en lenguas extranjeras: inglés. Bogotá, Colombia: Imprenta Nacional.

Ministerio de Educación Nacional [MEN]. (2007). Plan Nacional Decenal de Educación 2006-2016. Bogotá: Colombia. Imprenta Nacional.

Ministerio de Educación Nacional [MEN]. (2013). Ley 1651 de Bilingüismo. Retrieved from https://www.funcionpublica.gov.co/ eva/gestornormativo/norma.php?i=53770

Ministerio de Educación Nacional [MEN] (2014). Colombia Very Well! Programa NacionaldeInglés2015-2025. Retrievedfrom https://www.mineducacion.gov.co/1759/ articles-343837_Programa_Nacional_ Ingles.pdf

Montijano, Del P. (2014). Textbook use training in EFL teacher education. Utrecht Studies in Language \& Communication, 27, 267-286.

Mohseni, M. (2008). On the relationship between ESP \& EGP: A general perspective. English for Specific Purposes World Issue. 7(17), 1-11

Núñez A. (2009) On the Road Student's Book 1 for Beginners. Bogotá, Colombia: Fundación Universitaria Empresarial de la Cámara de Comercio de Bogotá Uniempresarial.

Núñez, A. (2010a) The teaching of English within the theory-practice alternance model. In: Innovación y Competitividad Jornada de Investigación, (pp. 32-54).
Dirección de Investigaciones y Estudios Empresariales de la Cámara de Comercio de Bogotá Uniempresarial.

Núñez, A. (2010b) On the road student's book 2 for elementary A. Bogotá, Colombia: Fundación Universitaria Empresarial de la Cámara de Comercio de Bogotá Uniempresarial.

Núñez, A. (2010c) Economics essentials. Bogotá, Colombia: Fundación Universitaria Empresarial de la Cámara de Comercio de Bogotá Uniempresarial.

Núñez, A. (2011) On the road student's Book 3 for elementary $B$. Bogotá, Colombia: Fundación Universitaria Empresarial de la Cámara de Comercio de Bogotá Uniempresarial.

Núñez-Pardo, A. (2018a). The English textbook. Tensions from an intercultural perspective. GiST Education and Learning Research Journal,17(2), 230-259.

Núñez, A. (2018b). Critical interculturality to disrupt coloniality in the English textbook. Revista Virtual Cuestiones Educativas, septiembre (1-9). Bogotá, Colombia: Universidad Externado de Colombia.

Núñez, A., Parga, F., \& Toquica, M. (2011) On the road student's book 5 for Pre-Intermediate B. Bogotá, Colombia: Fundación Universitaria Empresarial de la Cámara de Comercio de Bogotá Uniempresarial.

Núñez, A., Pineda, C., \& Téllez, M. (2004). Key aspects for developing your instructional materials. PROFILE: Issues in Teachers' Professional Development, 5, 128-139. Bogotá: Universidad Nacional de Colombia.

Núñez, A., \& Quiroga, C. (2011) On the road student's book 4 for pre-intermediate $A$. Bogotá, Colombia: Fundación Universitaria Empresarial de la Cámara de Comercio de Bogotá Uniempresarial.

Núñez, A., Ramos, B., \& Téllez, M. F. (2006). Reflexión en el contexto educativo: hacia la toma de decisiones en el aula [Reflection in 
the educational context: Towards decision making in the classroom]. @puntesCont@ bles, 11, 111-115.

Núñez, A., \& Téllez, M. (2008). Meeting students' needs. Enletawa Journal, 1, 65-68. Tunja, Boyacá: Universidad Pedagógica y Tecnológica de Colombia.

Núñez, A., \& Téllez, M. F. (2009). ELT Materials: The key to fostering effective teaching and learning settings. PROFILE: Issues in Teachers' Professional Development, 11(2), 173-186.

Núñez, A., \& Téllez, M. F. (2015). Reflection on teachers' personal and professional growth through a materials development seminar. HOW, 22(2), 54-74.

Núñez, A., \& Téllez, M.F. (2018). The argumentative competence through in-class debates. En A. Núñez, M.F. Téllez, \& J. Gómez (Eds.) (pp. 19-103). Teacher-developed materials for language teaching and learning. Departamento de Publicaciones Universidad Externado de Colombia.

Núñez-Pardo, A., \& Téllez-Téllez, M. (2020). Tracing the cultural component in teacher generated EFL materials. (in press). In: A, Núñez-Pardo \& M. F. Téllez (Eds.). Defying culture hegemony through teacher generated materials Bogotá, Colombia: Departamento de Publicaciones Universidad Externado de Colombia.

Núñez, A., Téllez, M. F., \& Castellanos, J. (2013). Proposal for the research line materials development and didactics (Ascribed to the Research Group: Critical Pedagogy and Didactics for Social Transformation). Universidad Externado de Colombia, Bogotá.

Núñez, A., Téllez, M., \& J. Castellanos (2012) A framework for materials development: A path for in-service teachers to build up the instructional design of their research projects. In A. Núñez, M. Téllez \& J. Castellanos (Eds.). Teacher research on English didactics issues. (pp. 17-38). Bogotá, Colombia: Departamento de Publicaciones Universidad Externado de Colombia.

Núñez, A., Téllez, M. F., \& Castellanos, J. (2017a). Materials development for teachers' professional growth. In A. Núñez, M. F. Téllez, \& J. Castellanos (Eds.), Materials for the learning of English and teachers' professional growth. (pp. 19-68). Bogotá, Colombia: Departamento de Publicaciones Universidad Externado de Colombia.

Núñez, A., Téllez, M. F., \& Castellanos, J. (2017b). Teacher-developed materials in a Master's programme in education with emphasis on English didactics. In A. Núñez, M. F. Téllez, \& J. Castellanos (Eds.), The role of teacher-developed materials in fostering English language skills. (pp. 13-56). Bogotá, Colombia: Departamento de Publicaciones Universidad Externado de Colombia.

Núñez, A., Téllez, M. F., Castellanos, J., \& Ramos, B. (2009). A practical materials development guide for EFL pre-service, novice, and in-service teachers. Bogotá, Colombia: Universidad Externado de Colombia.

O'Neill, R. (1990). Why use textbooks? ELT Journal 36(2), 106-111.

Oxford, R. (1997). Language learning strategies: What every teacher should know. Boston, MA: Heinle \& Heinle Publishers.

Pennycook, A. (1994). The cultural politics of English as an international language. New York, NY: Routledge.

Pineda, C. (2001). Developing and English as a foreign language curriculum: the need for an articulated framework. Colombian Applied Linguistic Journal, 3(1), 6-20.

Pulverness, A., \& Tomlinson, B. (2013). Materials for cultural awareness. In: B. Tomlinson (Ed.), Developing materials for language teaching (pp. 443-459). London, UK: Bloomsbury Publishing Plc. 
Ramos, B., \& Aguirre, J. (2014). Materials development in the Colombian context: Some considerations about its benefits and challenges. HOW, Colombian Journal for Teachers of English, 21, 134-150

Richards, J. C. (2001). Curriculum development in language teaching. Cambridge, UK: Cambridge University Press,

Rico, C. (2010). The effects of language materials on the development of on intercultural competence. In B. Tomlinson \& H. Masuhara (2010) (Eds.), Research for materials development in language learning evidence for best practice (pp. 84-102). London, UK: Continuum.

Rico, C. (2012). Language teaching materials as mediators for ICC development: A challenge for materials developers. Signo $y$ Pensamiento, 30(60), 130- 154.

Rossner, R. (1988). Materials for communicative language teaching and learning. Annual Review of Applied Linguistics, (8), 140-163

Sandin, M. P. (2003). Investigación cualitativa en educación: fundamentos y tradiciones [Qualitative research in education: Fundamentals and traditions]. Barcelona, España: Mc Graw Hill.

Schwandt, T. A., Denzin, N. K., \& Lincoln, Y. S. (1994). Handbook of qualitative research. London, UK: Denzin \& Lincoln.

Seedhouse, P. (1995). Needs analysis and the general English classroom. ELT Journal 49(1), 59-65.

Strauss, A.L., \& Corbin, J. (1994). Grounded theory methodology: An overview. In N.K. Denzin \& Y.S. Lincoln (Eds.), Handbook of qualitative research. Thousand Oaks, CA: Sage Publications.

Swales, J. (1990). Genre analysis: English in academic and research settings. Cambridge, MA: Cambridge University Press.

Thomas, C. (2014). Meeting EFL learners halfway by using locally relevant authentic materials. English Teaching Forum, 52(3), 14-23

Tomlinson, B. (1998). Materials development in language teaching. Cambridge, MA: Cambridge University Press.

Tomlinson, B. (Ed.) (2003). Developing materials for language teaching. London, UK: Continuum.

Tomlinson, B., \& Masuhara, H. (2010). (Eds.) Research for materials development in language learning evidence for best practice. London, UK: Continuum.

Usma, J. (2009). Education and language policy in Colombia: Exploring processes of inclusion, exclusion, and stratification in times of global reform. PROFILE Issues in Teachers' Professional Development, 11, 123-141.

Valencia, S. (2006). Texts, and talk around the texts: English language teaching developments in Colombia. Colombian Applied Linguistic Journal Literacy Practices. 8, 7-37.

Yin, R. (1994). Case study research: Design and methods (2nd ed.). Beverly Hills, CA: Sage Publishing.

Zonabend, F. (1992). The monograph in European ethnology. Current Sociology, 40(1), 49-60. 


\section{Appendix A}

\section{Guion del grupo focal (focus group)}

\section{Agenda}

1. Bienvenida o apertura

2. Revisión de la agenda

3. Revisión del objetivo del encuentro

4. Revisión de las normas básicas/reglas del juego

5. Presentación de los miembros

6. Lectura de preguntas y respuestas

7. Cierre de la sesión

\section{Bienvenida y apertura}

Apreciados estudiantes: nuestra fundación universitaria, a través de su Centro de Idiomas (FLC), les da la bienvenida y agradece de antemano su interés y buena disposición para asistir a este encuentro.

\section{Revisión de la agenda}

Nuestra agenda incluye siete aspectos centrales, los cuales deben desarrollarse en tiempo real correspondiente a 60 o 90 minutos. Por esta razón, se solicita concentración y diligencia en el desarrollo de misma.

\section{Revisión del objetivo del encuentro}

El Centro de idiomas (FLC) adelanta un proyecto de investigación cuyo objetivo es analizar la relevancia del desarrollo e implementación de una serie institucional de inglés basada en el uso de estrategias que combina inglés con propósitos generales y específicos para los estudiantes de pregrado en el modelo dual. Considerando su espíritu participativo y reflexivo, usted ha sido seleccionado como uno de los miembros del grupo focal, cuyas percepciones contribuirán al logro de los objetivos propuestos por nuestro estudio.

\section{Revisión de las normas básicas/reglas del juego}

Les agradecemos su tiempo y atención al leer las preguntas cuidadosamente, discutirlas con los demás miembros del grupo y finalmente elaborar una conclusión que resuma los puntos esenciales de su intervención.

\section{Presentación de los miembros}

Cada uno de los miembros del grupo dispone de dos minutos para hacer su respectiva presentación personal (nombre y edad) y como estudiante del modelo dual (promoción a la cual pertenece y el semestre que adelanta). 


\section{Lectura de preguntas y elaboración de respuestas}

1. ¿Considera que en el modelo de alternancia, el idioma inglés es un componente importante o no dentro de su formación académica o curricular? ¿Por qué?

2. ¿Qué piensa de la combinación de los dos componentes, inglés con Propósitos Generales (EGP: el que se emplea para la comunicación en la vida diaria) e inglés con Propósitos Específicos (ESP: el que se emplea en las distintas áreas del conocimiento como mercadeo, administración, finanzas contaduría, turismo, etc.) en la formación de los futuros profesionales del modelo dual? ¿Por qué?

3. ¿Cree que contribuye o no la idea de diseñar, pilotear y validar nuestra propia serie de textos, On the Road, para la enseñanza del inglés bajo la modalidad de alternancia?

4. ¿Encuentra los textos de inglés desarrollados para el primer nivel (Beginners) y el segundo nivel (Elementary A) de nuestra serie On the Road, acordes o no con sus expectativas en relación con el proceso de aprendizaje, los contenidos, el tipo de actividades, el uso de estrategias de aprendizaje, la secuencia y el diseño?

¿Por qué? (El diseño es unicolor para posibilitar su venta a precios razonables y accesibles a los estudiantes de nuestra institución).

5. ¿Si tuviera la posibilidad de adicionar contenidos y actividades, ¿cuáles incluiría? ¿Por qué?

6. Si tuviera la posibilidad de reducir o eliminar contenidos y actividades, ¿cuáles seleccionaría? ¿Por qué?

\section{Cierre de la sesión}

Apreciados estudiantes, nuestra institución, y más particularmente nuestro Centro de Idiomas (FLC), agradece su amable atención, oportuna asistencia y colaboración. Sus opiniones constituyen un valioso aporte para la consecución de los objetivos de nuestro proyecto de investigación.

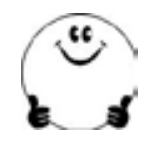

\section{Appendix B}

\section{Field Notes Form}

Research question: What is revealed about the development and implementation of an in-house strategy-based English series that combines English for General Purposes (EGP) and English for Specific Purposes (ESP) among undergraduates in the theory-practice dual model?

\section{Date:}

\section{Unit and topic:}

\section{Students:}

\section{Teacher:}




\begin{tabular}{|c|c|c|}
\hline Line & Field notes & Analysis \\
\hline 1 & & \\
\hline 2 & & \\
\hline 3 & & \\
\hline 4 & & \\
\hline 5 & & \\
\hline 6 & & \\
\hline 7 & & \\
\hline 8 & & \\
\hline 9 & & \\
\hline 10 & & \\
\hline 11 & & \\
\hline 12 & & \\
\hline 13 & & \\
\hline 14 & & \\
\hline 15 & & \\
\hline 16 & & \\
\hline 17 & & \\
\hline 18 & & \\
\hline 19 & & \\
\hline 20 & & \\
\hline 21 & & \\
\hline 22 & & \\
\hline 23 & & \\
\hline 25 & & \\
\hline 26 & & \\
\hline 27 & & \\
\hline 28 & & \\
\hline 29 & & \\
\hline 30 & & \\
\hline
\end{tabular}

